STUDIA HISTORICA GEDANENSIA

TOM XII (2021)

\author{
Iwona Janicka \\ (Uniwersytet Gdański) \\ https://orcid.org/0000-0002-7922-8504
}

\title{
Cholera a COVID-19. Różne choroby, wspólna profilaktyka
}

Słowa kluczowe: cholera, COVID-19, koronawirus, profilaktyka Keywords: cholera, COVID-19, coronavirus, prevention

Cholera i COVID-19 to dwie różne choroby, które pochodzą z jednego kontynentu - Azji, choć z różnych jej części. Pierwszą wywołuje bakteria nazywana od swojego kształtu przecinkowcem cholery (Vibrio cholerae), która endemicznie występuje w północnych Indiach. Drugą powoduje zaliczany do koronawirusów wirus SARS-CoV-2, rozprzestrzeniający się po świecie ze środkowych Chin $^{1}$. Zadanie porównania ich patogenezy, przebiegu i sposobu leczenia jest bardzo ryzykowne, o ile w ogóle możliwe, dlatego trudno się go podjąć, będąc historykiem, a nie lekarzem. Jest jednak płaszczyzna, na której można wskazać - oczywiście $\mathrm{z}$ historycznego punktu widzenia - pewne wspólne mianowniki pandemii cholery i COVID-19. Tą wspólną płaszczyzną jest profilaktyka antyepidemiczna.

Cholera jest chorobą już dobrze rozpoznaną i zarówno lekarze, jak i historycy poświęcili jej sporo publikacji. W obszarze naszych zainteresowań badawczych znajdzie się głównie Cesarstwo Rosyjskie, stąd dokonywane porównania będą się

1 Cholera endemicznie występuje w północno-wschodnich Indiach, a szczególnie w dorzeczu rzek Ganges i Brahmaputra oraz w położonej między nimi historycznej prowincji Bengal w Azji Południowej. Pierwsza pandemia tej choroby wybuchła w 1817 r., ale po raz pierwszy cholera dotarła do Europy w 1831 r., a do obu Ameryk - w 1832 r. Z kolei pierwsze przypadki COVID-19 odnotowano w listopadzie 2019 r. w mieście Wuhan, w prowincji Hubei w środkowych Chinach, Christopher Hamlin, Cholera. The biography (Oxford: Oxford University Press, 2009), 18; Myron Echenberg, Africa in the time of cholera. A history of pandemics from 1815 to the present (New York: Cambridge University Press, 2011), 17; Isaac Scher, „The first COVID-19 case originated on November 17, according to Chinese officials searching for 'patient zero'", Insider (2020), https://www.businessinsider.com/coronavirus-patients-zero-contracted-case-november2020-3?IR=T, dostęp: 5 II $2021 \mathrm{r}$. 
odnosić przede wszystkim do tego kraju. Spośród bogatej literatury opisującej chronologię pandemii cholery, ich przebieg, szeroko pojęte skutki, warto wskazać między innymi opracowanie rosyjskiego lekarza Grigorija Archangielskiego. Brał on czynny udział w walce $\mathrm{z}$ cholerą w latach sześćdziesiątych i siedemdziesiątych XIX w., a następnie w swej dysertacji doktorskiej zbadał kierunki rozprzestrzeniania się i statystykę choroby w całej Rosji w latach $1823-1872^{2}$. Pomimo nieścisłości przedstawionych przez niego danych liczbowych (co wynikało m.in. z braku kompletnych raportów, niesystematyczności, nierzetelności urzędników je sporządzających itp. $)^{3}$ jest to jedno z ważniejszych i kompleksowych opracowań na ten temat ${ }^{4}$. Podobnych, zwłaszcza późniejszych, jest oczywiście znacznie więcej, jednak wszystkie odwołują się do ustaleń właśnie Archangielskiego. Problematykę cholery w innych krajach chętnie podejmowano (i nadal się podejmuje) w pracach anglojęzycznych, niemieckich i innych. Wśród nich dla przykładu wskazać można monografie Petera Baldwina, Christophera Hamlina, Richarda Johna Evansa, Rodericka McGrew czy Barbary Dettke ${ }^{5}$. Również na gruncie polskim powstały liczne publikacje poświęcone tej chorobie, między innymi autorstwa Rościsława Stascha, Marka Pawła Czaplińskiego, Adama Szarszewskiego, Edmunda Kizika, Konrada Wnęka ${ }^{6} \mathrm{i}$ innych, także piszącej te słowa ${ }^{7}$.

2 Grigorij Ivanovič Arhangel'skij, Holernyâ èpidemii v Evropejskoj Rossii v 50-ti-letnij period 1823-1872 gg. Dissertaciâ na stepen' doktora mediciny (Sankt Peterburg: Tipografiâ Michaila Stasûleviča, 1874).

3 Szerzej na ten temat: Zbigniew Jastrzębowski, „Polska statystyka medyczna a badania nad zdrowotnością społeczeństwa polskiego w XIX wieku”, Medycyna Nowożytna 3/1-2 (1996): 118-119.

4 Jego wyliczenia odnośnie do północno-zachodnich guberni zostały na nowo przeliczone i skorygowane w monografii: Iwona Janicka, Sina śmierć z Azji. Epidemie cholery w pótnocno-zachodnich guberniach Cesarstwa Rosyjskiego w XIX wieku (Gdańsk: Uniwersytet Gdański, 2021). Badaniami objęto tu cały okres występowania choroby w XIX w., a zatem lata 1831-1895.

5 Peter Baldwin, Contagion and the State in Europe 1830-1930 (Los Angeles: University of California, 1999); Hamlin, Cholera; Richard J. Evans, Death in Hamburg. Society and Politics in the Cholera Years 1830-1910 (Oxford: Clarendon Press, 1990); Roderick E. McGrew, Russia and the cholera 1823-1832 (Madison: University of Wisconsin Press, 1965); Barbara Dettke, Die asiatische Hydra. Die Cholera von 1830/31 in Berlin und den preußischen Provinzen Posen, Preußen und Schlesien (Berlin-New York: De Gruyter, 1995).

6 Rościsław Stasch, Epidemja cholery azjatyckiej w Poznaniu w 1831 roku (Poznań: Adam Wrzosek, 1933); Marek Paweł Czapliński, Epidemie cholery w rejencji opolskiej w latach 1831-1894 (Rybnik: Stowarzyszenie Humanistyczne: Europa, Śląsk, Świat Najmniejszy, 2012); Adam Szarszewski, „Epidemie cholery w Gdańsku w XIX wieku”, w Dżuma, ospa, cholera. W trzechsetna rocznicę wielkiej epidemii w Gdańsku i na ziemiach Rzeczypospolitej w latach 1708-1711. Materiały z konferencji naukowej, red. Edmund Kizik (Gdańsk: Muzeum Historyczne Miasta Gdańska, Instytut Historii PAN, 2012), 195-211; Edmund Kizik, „Gdańsk i Elbląg w czasach zarazy 1709-1710 roku”, w ibidem, 99-111; Konrad Wnęk, „Epidemia cholery w Krakowie w 1866 roku. Analiza demograficzna i przestrzenna, Przeszłość Demograficzna Polski 37, 3 (2015): 93-117.

7 Przykładowe publikacje: Iwona Janicka, „Kwestia pochówku zmarłych na cholerę w północno-zachodnich guberniach Cesarstwa Rosyjskiego w XIX wieku”, w Dżuma, ospa, cholera, 212-223; eadem, „Organizacja i działanie kwarantann morskich w portach w czasie epidemii cholery w Rosji 
COVID-19 jest chorobą nową, ale wiedzę o niej uzyskujemy znacznie szybciej niż o cholerze w XIX w. Obecnie na jej temat jest wiele pomniejszych artykułów naukowych autorstwa lekarzy, także dziennikarzy, zwłaszcza na stronach internetowych, ale brakuje obszerniejszej publikacji, choć z pewnością jej powstanie jest tylko kwestią czasu. System monitoringu pandemii jest na tyle rozwinięty, że pozwala bardzo szybko zbierać różnorodne dane, porównywać je i wyciągać pewne wnioski, jednak w związku z tym że choroba ciągle ewoluuje i co jakiś czas ujawnia swoje nowe, nieznane strony (pojawiają się także różne jej „terytorialne” odmiany), należy do wszystkich publikacji odnosić się z pewną rezerwą i ostrożnością. Z tego powodu zastrzec należy, że jest bardzo prawdopodobne, iż w chwili, gdy ukaże się ten tekst, stan badań nad COVID-19 będzie już zaawansowany, przez co niektóre informacje w nim zawarte mogą być już nieaktualne.

Obie choroby wiele różni, zwłaszcza czynnik etiologiczny, można jednak postawić tezę, że profilaktyka przeciwko cholerze i COVID-19 ma kilka punktów stycznych. Zacznijmy od tego, że wśród działań prowadzonych w tym zakresie obecnie, podobnie jak w XIX w., można wskazać te o charakterze higieniczno-sanitarnym oraz medyczno-policyjnym. Przyjrzyjmy się niektórym z nich.

Tabela. Środki i działania profilaktyczne wspólne dla pandemii cholery w XIX w. oraz pandemii COVID-19 w XXI w.

\begin{tabular}{|l|l|}
\hline \multicolumn{1}{|c|}{ Higieniczno-sanitarne } & \multicolumn{1}{c|}{ Medyczno-policyjne } \\
\hline $\begin{array}{l}\text { dezynfekcja rąk oraz przedmiotów, które mogły } \\
\text { mieć styczność z zarażonymi }\end{array}$ & $\begin{array}{l}\text { zakaz/ograniczenie przemieszczania się, izolacja } \\
\text { domowa }\end{array}$ \\
\hline $\begin{array}{l}\text { dbanie o czystość i porządek w gospodarstwie } \\
\text { domowym }\end{array}$ & $\begin{array}{l}\text { kontrola stanu zdrowia podróżnych na grani- } \\
\text { cach, konieczność posiadania zaświadczenia } \\
\text { o stanie zdrowia }\end{array}$ \\
\hline $\begin{array}{l}\text { ogólna dbałość o higienę osobistą, zdrowie, } \\
\text { samoobserwacja }\end{array}$ & kwarantanna \\
\hline dbanie o zdrowie psychiczne & ograniczenie handlu i dostępności usług \\
\hline & zamykanie szkół, placówek kultury \\
\hline & $\begin{array}{l}\text { zakaz/ograniczenie spotkań towarzyskich, roz- } \\
\text { rywek oraz imprez publicznych }\end{array}$ \\
\hline & $\begin{array}{l}\text { stosowanie środków przymusu, kar za niedosto- } \\
\text { sowanie się do zaleceń rządowych }\end{array}$ \\
\hline
\end{tabular}

w XIX wieku”, w Morze nasze i nie nasze. Zbiór studiów, red. Piotr Kurpiewski, Tadeusz Stegner (Gdańsk: Wydawnictwo Uniwersytetu Gdańskiego, 2011), 89-113; eadem, „Organizacja służb medycznych w czasie epidemii cholery w XIX wieku na terenie północno-zachodnich guberni Cesarstwa Rosyjskiego", w Między Zachodem a Wschodem, t. 5: Kondycja zdrowotna i demograficzna społeczeństwa polskiego na przestrzeni wieków, red. Krzysztof Mikulski, Agnieszka Zielińska, Katarzyna Pękacka-Falkowska (Toruń: Wydawnictwo Naukowe Grado, 2011), 39-53. 


\begin{tabular}{|l|l|}
\hline \multicolumn{1}{|c|}{ Higieniczno-sanitarne } & \multicolumn{1}{|c|}{ Medyczno-policyjne } \\
\hline & $\begin{array}{l}\text { wzmożone użycie wojsk i policji, m.in. do two- } \\
\text { rzenia kordonów na granicach, kontroli ludności } \\
\text { na ulicach }\end{array}$ \\
\hline & $\begin{array}{l}\text { tworzenie tymczasowych szpitali dla chorych, } \\
\text { zwiększenie zatrudnienia personelu medycznego }\end{array}$ \\
\hline & szczepienia \\
\hline
\end{tabular}

Źródło: opracowanie własne.

Środki i działania higieniczno-sanitarne mają charakter indywidualny i dotyczą każdej osoby oraz przestrzeni, w której dana osoba żyje lub stale czy też okresowo przebywa. Jednym z najważniejszych są zabiegi higieniczne, takie jak częste mycie i dezynfekcja rąk, przedmiotów osobistych oraz różnych sprzętów, z którymi kontakt mogli mieć zarażeni. Celem tego zabiegu jest dekontaminacja, czyli usuwanie i dezaktywowanie czynnika biologicznego wywołującego chorobę. W czasie dziewiętnastowiecznych epidemii cholery dezynfekcję przeprowadzano przed wybuchem epidemii, w trakcie jej trwania oraz po jej wygaśnięciu. W zależności od tego, co miało być poddane dezynfekcji - ciało, przedmioty czy miejsce, używano środków o różnych stanach skupienia - stałym, ciekłym i gazowym. Na przykład sublimatem (chlorkiem rtęci) lub jego mieszaniną z kwasem karbolowym (dziś nazywanym fenolem) albo jeszcze popularniejszym tzw. mlekiem wapiennym (wodna zawiesina wodorotlenku wapnia) odkażano uprzednio umyte podłogi, ściany, drzwi, a także przedmioty skórzane, kauczukowe, gumowe ${ }^{8}$. $Z$ biegiem czasu zasób środków i sposobów dezynfekowania powiększał się, ale podczas pierwszych pandemii, kiedy jeszcze nie wiedziano, w jaki sposób jest przenoszona choroba, stosowanie części z nich, na przykład fumigantów do odkażania powietrza (np. octu, kadzideł roślinnych), nie miało żadnego uzasadnienia ${ }^{9}$. Inne z kolei, jak roztwór

8 Stanisław Serkowski, Dezynfekcja przy chorobach zakaźnych (Warszawa: Drukarnia Artystyczna Kazimierz Kopytkowski i S-ka, 1915), 33-35; Antoni Puławski, Co to jest cholera i jak się od niej bronić?, wyd. 3 (Warszawa: Druk J. Sikorskiego, 1915), 11.

9 Na pytania, co wywołuje cholerę oraz w jaki sposób jest ona przenoszona, próbowano odpowiedzieć od pierwszej pandemii. Jednak dopiero od połowy XIX w. badania zaczęto prowadzić we właściwym kierunku. Szczególne zasługi w odkryciu patogenu cholery oraz drogi jej transmisji mieli m.in. angielski lekarz John Snow (podczas epidemii cholery w Londynie najpierw w 1849 r., a później w 1854 r. udowodnił, że kierunek rozprzestrzeniania się choroby pokrywa się z biegiem sieci wodociągowej), Filippo Pacini (również w 1854 r., wykonując autopsję ofiar cholery we Florencji, odkrył bakterię, którą uznał za patogen choroby) oraz Robert Koch (w latach 1883-1884 podczas ekspedycji do Egiptu oraz Indii zaobserwował bakterię cholery w kale cholerycznych, oznaczył ją jako Vibrio cholerae i dowiódł jej obecności w wodzie), John Snow, On the Mode of Communication of Cholera (London: John Churchill, 1849); idem, On the Mode of Communication of Cholera (London: John Churchill, 1855), 86; Norman Howard-Jones, The scientific background of the International Sanitary Conferences 1851-1938 (Genewa: WHO, 1975), 17; Echenberg, Africa, 38-39; S.L. Kotar, J.E. Gessler, Cholera. A Worldwide History (Jefferson: McFarland \& Company, 2014), 237-238. 
kwasu karbolowego, sublimatu czy mleka wapiennego, sprawdzały się, o ile przygotowano je w odpowiedni sposób. Zasadniczą kwestią, podobnie jak dziśs, była higiena ciała, zwłaszcza rąk. Do ich mycia oprócz mydła używano karbolu, spirytusu albo roztworu chlorynowego ${ }^{10}$. Wraz z powstawaniem w miastach komór dezynfekcyjnych w końcu XIX i na początku XX w. upowszechniła się właśnie ta metoda dezynfekcji. W komorach formalinowych odkażano na przykład książki, dokumenty, a w parowych - materace, kołdry, pierze, bieliznę, ubrania, dywany, firany, naczynia szklane, fajansowe i metalowe ${ }^{11}$.

Instrukcje rządowe oraz różne poradniki i traktaty medyczne zwracały uwagę na konieczność utrzymywania porządku w domu i obejściu, czyli na podwórkach, w ustępach, które w XIX w. znajdowały się jeszcze głównie na zewnątrz. Ekskrementy w nich miały być zasypywane niegaszonym wapnem lub polewane chlorkiem wapnia, podobnie zresztą jak śmietniki i doły na pomyje ${ }^{12}$.

Podczas pandemii COVID-19 higiena i dezynfekcja rąk oraz różnych przedmiotów również ma kluczowe znaczenie dla zapobiegania zarażeniom oraz powstrzymania rozprzestrzeniania się choroby. Do higieny rąk, oprócz tak podstawowych i ogólnodostępnych środków, jak mydło oraz ciepła woda, zaleca się płyny dezynfekujące oraz żele antybakteryjne z wysoką (powyżej 65\%) zawartością alkoholu. Badania naukowe dowodzą, że odpowiednio dokładne mycie rąk zmniejsza ryzyko zachorowania nawet o połowę ${ }^{13}$. Należy jednak robić to w odpowiedni sposób i często. Ponieważ choroba popularnie nazywana koronawirusem rozprzestrzenia się drogą kropelkową, spektrum działania wirusa jest o wiele szersze aniżeli bakterii. Co za tym idzie, dezynfekcji podlegać muszą także wszystkie przedmioty i rzeczy, których używamy lub dotykamy w miejscach publicznych czy miejscu pracy. Chodzi tu zarówno o rzeczy osobiste, jak i te, które mogły mieć kontakt z innymi osobami, na przykład telefony, klucze, karty płatnicze, komputery, klamki drzwi, wind (także przyciski w nich), obuwie, odzież, wyroby skórzane itp. Dodatkowym zabezpieczeniem są maseczki zasłaniające twarz i usta oraz jednorazowe rękawiczki ${ }^{14}$. To środki podstawowe wymagane od zwykłej ludności, w przypadku służb medycznych ich zasób jest jednak szerszy i obejmuje jeszcze gogle oraz specjalistyczne kombinezony.

10 „Instrukcja o środkach osobistego zabezpieczenia się przed cholerą”, w Sbornik dejstvuîsih rasporâženij Ministerstva Narodnago Prosveŝeniâ o zakrytii mužskoj gimazii po slučaû poâvleniâ zaraznyh zabolevanij, sost. i izd. A.I. Syromâtnikov (Odessa 1911), 23.

11 Serkowski, Dezynfekcja, 33-35.

12 Ibidem, 25; Henryk Rundo, O cholerze zkąd do nas przychodzi, jaka jest jej przyczyna, i w jaki sposób jej się ustrzedz można (Łódź 1905), 17.

13 Dezynfekcja i sterylizacja w czasach epidemii chroni przed zakażeniem. Jak ja wykonać w domowych warunkach?, https://www.enbio.com/pl/blog/post/dezynfekcja-sterylizacja-jak-jawykonac-w-domu, dostęp: 11 II $2021 \mathrm{r}$.

14 Ibidem. 
Ważnymi elementami profilaktyki w obu chorobach jest ogólna dbałość o stan zdrowia fizycznego, a zwłaszcza niedopuszczenie do przeziębienia. Dawni lekarze wierzyli, że może się ono łatwo się przerodzić w cholerę, podobnie zresztą jak różne dolegliwości żołądkowe. W dziewiętnastowiecznych instrukcjach radzono więc, aby nie pozostawać na noc na dworze, nie leżeć lub nie spać na gołej ziemi, nie nosić przemoczonej odzieży, zwłaszcza butów, zbyt lekko się nie ubierać, nie wychodzić do pracy z pustym żołądkiem i w ogóle dbać o odpowiednią jakość spożywanych posiłków ${ }^{15}$. W przypadku COVID-19 niektóre z jego objawów są podobne do przeziębienia, w związku z czym istnieje niebezpieczeństwo postawienia złej diagnozy i pomylenia chorób, zwłaszcza gdy choremu nie zostanie wykonany test na obecność wirusa. $Z$ tego powodu obserwowanie swego stanu zdrowia oraz umiejętność jego poprawnego opisu są istotne. Należy zwrócić uwagę, że równie ważne jest zdrowie psychiczne. Dawniej lekarze wyznawali zasadę, że „szczęśliwych plaga się nie ima”, w związku z czym przestrzegano przed uleganiem strachowi, radzono zachować spokój ducha, nie rozważać bolesnych i smutnych wydarzeń ${ }^{16}$. Chodziło prawdopodobnie o to, by nie pogłębiać i tak już ponurych nastrojów oraz by nie zniechęcić ludności do podejmowania się opieki nad chorymi. W czasie obecnej pandemii wydaje się, że o zdrowiu psychicznym mówi się raczej w kontekście skutków przedłużającego się odosobnienia i różnych innych ograniczeń. Jedno z przykładowych badań przeprowadzonych w kwietniu 2020 r. na grupie ponad 400 respondentów pokazało, że nasz stan psychiczny w porównaniu z normą populacyjną uległ znacznemu pogorszeniu. Podwyższył się poziom niepokoju, zwiększyły się problemy ze snem, w wielu przypadkach wzrósł poziom agresji, zaczęto chorować na depresję. Zaburzenia funkcjonowania zdrowia psychicznego w czasie pierwszej fali pandemii wystąpiły u ponad $26 \%$ badanych, a więc u co czwartej osoby ${ }^{17}$. Należy spodziewać się, że w czasie kolejnych fal choroby, wraz ze wzrostem obostrzeń, wynik ten będzie jeszcze gorszy. Niestety, dla epidemii cholery w XIX w., podobnie zresztą jak dla innych chorób, nie mamy takich badań. Możemy za to podać konkretne przykłady eksponowania frustracyjnych zachowań. Są to choćby bunty choleryczne, do których doszło

${ }_{15}$ Przepis dotyczacy środków osobistego uchronienia się od cholery, opracowany przez Radę lekarska (Warszawa: Dzien. Rady lekarskiej z dn. 1 kwietnia 1908 r.), 7.

16 Wiadomość o cholerze, podana przez Radę Ogólna Lekarska Królestwa Polskiego (Kalisz 1831), 13-14; Szymon Wrzesiński, Oddech śmierci. Życie codzienne podczas epidemii (Kraków: Egis, 2008), 105.

17 Monika Talarowska, Joanna Chodkiewicz, Natalia Nawrocka, Joanna Miniszewska, Zdrowie psychiczne a epidemia SARS-COV-2 - badania polskie, 7, 15, https://www.researchgate.net/profile/ Monika_Talarowska2/publication/342845107_Mental_health_and_the_epidemic_SARS-COV-2_-_ risk_factors_Polish_research_Zdrowie_psychiczne_a_epidemia_SARS-COV-2_-badania_polskie/ links/5f087659a6fdcc4ca45bcf88/Mental-health-and-the-epidemic-SARS-COV-2-risk-factors-Polishresearch-Zdrowie-psychiczne-a-epidemia-SARS-COV-2-badania-polskie.pdf, dostęp: 11 II $2021 \mathrm{r}$. 
w Moskwie (1830 r. $)^{18}$, Sankt Petersburgu (1831 r. $)^{19}$, Starej Russie $(1831 \text { r. })^{20}$, Astrachaniu (1892 r. $)^{21}$ i innych miejscach. Podczas wystąpień atakowano, a nawet zabijano lekarzy, urzędników, wybijano szyby w szpitalach, porywano chorych, często wyładowywano agresję na przedstawicielach różnych nacji, których posądzano o celowe roznoszenie zarazy, na przykład na Polakach ${ }^{22}$.

O ile środki higieniczno-sanitarne były zaleceniami, do których każdy stosował się (albo nie) indywidualnie i nie był przez nikogo kontrolowany, to środki i działania o charakterze medyczno-policyjnym w opisywanych pandemiach miały już charakter opresyjny. Ich wykonywanie było obowiązkowe, a za uchylanie się groziły kary pieniężne, konfiskaty, więzienie, a nawet śmierć, jak w przypadku bezprawnego przekroczenia kordonu sanitarno-wojskowego czy ucieczki z kwarantanny. Współcześnie stosowanie ostatniej z tych kar jest wykluczone, jednak środki przymusu prawnego mają zastosowanie.

Jednym z najbardziej uciążliwych środków wprowadzanych w czasie panowania obu opisywanych chorób zakaźnych była kwarantanna. Teoretycznie zasady jej odbywania dawniej i dziś są podobne i polegają na kilkunastodniowym odosobnieniu osoby lub osób, w stosunku do których mamy wątpliwości, czy są one zarażone, czy też nie (np. z powodu wcześniejszego kontaktu z zarażonym). W czasie izolacji nie wolno im było spotykać się z innymi, ich rzeczy i miejsce, w którym przebywały, wymagały dezynfekcji, a koszty pobytu w kwarantannie - jeśli konieczność jej odbycia dotknęła podróżujących - pokrywali oni sami. Różnice dostrzec możemy w długości jej trwania oraz miejscu zatrzymania. Choć termin „kwarantanna” pochodzi od łac. quarantena, czyli 40 dni, i teoretycznie tyle dni miała trwać izolacja, w praktyce w czasie cholery była ona krótsza. Zgodnie z ustawą kwarantannową z $1841 \mathrm{r}$. w Rosji podróżnych zatrzymywano na 14 dni, a osoby po przebytej chorobie, jeśli zostały zatrzymane $\mathrm{w}$ domach kwarantannowych, miały tam jeszcze przebywać na 28-dniowej obserwacji, podczas której były poddawane odkażaniu ${ }^{23}$.

W czasie obecnej epidemii termin kwarantanny wynosi generalnie $10 \mathrm{dni}$, przy czym jest on uzależniony od pewnych okoliczności. Kwarantanna może bowiem wynikać z powrotu do kraju, z ryzyka zakażenia koronawirusem (w obu

18 Gosudarstvennyj arhiv Rossijskoj Federacii (dalej: GARF), fond 109, opis 5, edinica Hronenâ 321, č. 1 (mikrofilm 1134), O posledovavših po slučaû poâvleniâ v Rossii èpidemičeskoj bolezni holery rasporâženiâh, 1830, karta 72 .

19 Azâatskaâ holera. V sžatom' monografičeskom'izloženii, red. M.I. Afanas'ev, P.B. Vaks" (S. Peterburg 1904), 5.

20 Bunt voennyh' poselân' v' holeru 1831 g. (Novgorod 1894), 2-5.

${ }^{21}$ Nikolaj F. Gamal"â, Holera i borba s" neûu (Odessa 1905), 60.

22 Do sytuacji takich dochodziło głównie w 1831 r., co miało bezpośredni związek z wojną polsko-rosyjską. Rosjanie uważali, że Polacy w odwecie np. zatruwają studnie czy sprzedają rzeczy po zmarłych. Atakami agresji padały nawet osoby podejrzane o polskie pochodzenie, GARF, f. 109, op.6, ed.hr. 798, č. 1, O besporâdkah vo vremâ holery, 1830, k. 131-131v.

${ }^{23} \mathrm{Nr} 14614,4$ iûnâ 1841, Vysočajše utverždennyj Ustav o Karantinah, $\$ 189,215-217$, w, Polnoe sobranie zakonov Rossijskoj imperii, sobranie 1825-1881, t. 16 (1841), 1. 
przypadkach wynosi ona $10 \mathrm{dni}$ ) lub z powodu wydania przez lekarza skierowania na wykonanie testu na koronawirusa (wówczas trwa do czasu uzyskania wyniku testu). Kwarantanna osoby, która mieszka z osobą chorą na COVID-19 i przebywającą w izolacji domowej, trwa z kolei tyle, ile wynosi izolacja osoby zakażonej plus siedem dni. Na izolację domową trafia się także automatycznie, jeśli otrzyma się pozytywny wynik testu na koronawirusa ${ }^{24}$.

Dawniej odosobnienie podróżnych przebiegało we wspomnianych domach kwarantannowych, czyli budynkach specjalnie zaplanowanych z myślą o rozdzieleniu osób „podejrzanych” od już chorujących na cholerę czy tylko poddawanych „oczyszczaniu”. Wznoszono je na granicach państw, w portach (kwarantanny zewnętrzne) oraz w miejscach nasilonego ruchu komunikacyjnego, na przykład pomiędzy miastami (tzw. kwarantanny wewnętrzne). Wzorowo urządzonych zakładów, takich jak w Marsylii czy Odessie, w tamtym czasie było jednak mało ${ }^{25}$. Zdecydowana większość z nich nie mieściła się w murowanych budynkach, lecz prowizorycznych, budowanych naprędce barakach, wynajmowanych szopach, stodołach. Nierzadko też we wspólnym pomieszczeniu przebywała znaczna liczba osób, które musiały tam spędzić różną liczbę dni. Wskutek tego, gdy ktoś faktycznie zachorował, termin izolacji wydłużano wszystkim i zamiast 14 dni niekiedy trzeba było w niej spędzić nawet miesiąc ${ }^{26}$. Było to ogromnie uciążliwe dla podróżujących, zwłaszcza gdy byli to kupcy. Ale podobnie jak i dziś, kwarantannę można było odbyć również we własnym domu. Jeżeli bowiem zachorował ktoś z domowników, ograniczano kontakt ze światem zewnętrznym również pozostałym. Łatwiej było to odosobnienie znieść na wsi. W mieście bowiem domy lub kamienice zamykano na klucz i znakowano przez wywieszenie tabliczki z napisem „cholera”. Nadzór nad izolowanymi był jednak zazwyczaj ograniczony i polegał głównie na dostarczaniu im żywności przez specjalnie przydzielonych do każdego kwartału dozorców oraz ewentualnie na odwiedzinach izolowanych przez lekarza ${ }^{27}$. Dziś kontrolę tę sprawują służby mundurowe (policja, straż miejska) oraz inne instytucje. Oprócz

24 Krótsza kwarantanna, https://pacjent.gov.pl/aktualnosc/krotsza-kwarantanna, dostęp: $15 \mathrm{~V} 2021 \mathrm{r}$.

25 Szczegółowo o funkcjonowaniu takiej wzorowo urządzonej kwarantanny na przykładzie Odessy zob. Janicka, Organizacja i działanie kwarantann morskich, 89-113.

26 Eadem, Sina śmierć z Azji, 315.

27 Zgodnie z ówczesnymi przepisami antyepidemicznymi wszystkie zamieszkałe tereny dzielono na mniejsze jednostki administracyjne, tj. wsie na części, miasta na części i kwartały, a powiaty na okręgi sanitarne. Każda z nich poddana była kurateli dozorcy, który zbierał wiadomości o stanie zdrowia mieszkańców, kontrolował warunki życia i w razie potrzeby sprowadzał do chorych lekarza lub w przypadku podejrzenia o chorobę dostarczał żywność do odizolowanych domów. Mieszkańcy zamówienia składali na kartkach opuszczanych w koszach. Tą samą drogą otrzymywali zakupione produkty i płacili za nie, Rossijskij gosudarstvennyj istoričeskij arhiv, f. 797, op. 3, d. 10092a, mf čast'2, Svedeniâ o poâvlenii, rasprostranenii i prekraŝenii holery po raznym guberniâm, 1892, k. 219v; Lietuvos valstybès istorijos archyvas, fond 378 , apyrašas b/s1830, saugojimo vienetas 463, Pravila i sposoby..., k. 7-7v; Janicka, Sina śmierć z Azji, 255. 
kontaktu osobistego (odwiedziny funkcjonariuszy) wykorzystuje się nowoczesne narzędzia, jak komórki czy komputery. Pozwalają one zlokalizować zatrzymanego oraz udokumentować jego faktyczne odosobnienie.

Wraz z kwarantannami w XIX w. wprowadzano również kordony sanitarno-wojskowe oraz ograniczenie możliwości przemieszczania się. Wyznaczano drogi i przejścia graniczne dla podróżnych, żądano od nich poddania się badaniu lekarskiemu (tzw. oglądowi), posiadania zaświadczeń o stanie zdrowia (tzw. paszportów) wystawionych przez władze miejsc, z których przybywali. Wszystkich poddawano dezynfekcji, podobnie zresztą jak przewożone rzeczy i towary. Środki te wymagały zaangażowania wojsk, zwłaszcza do tworzenia kordonów na granicach państwa, guberni czy powiatów. Nierzadko ludność cywilna samoorganizowała się i samorzutnie podejmowała własne środki bezpieczeństwa. Robili tak zwłaszcza mieszkańcy wsi, którzy odcinali się od świata, okopując się rowami, budując palisady czy zarzucając różnymi przeszkodami prowadzące do wsi drogi ${ }^{28}$. Wprawdzie współcześnie nie stosuje się aż tak drastycznych metod, tym niemniej w czasie szczytu pandemii koronawirusa wstrzymano ruch graniczny, wprowadzono ograniczenie przemieszczania się między miastami, a dla osób przekraczających granice wprowadzono obowiązek posiadania aktualnego negatywnego testu na obecność wirusa. Władze posiłkują się przy wykonywaniu przepisów między innymi Wojskami Obrony Terytorialnej.

Ograniczenie kontaktów towarzyskich, gromadzenia się ludności w miejscach publicznych, zawieszenie działalności różnych instytucji - to kolejne podobieństwa w stosowanych w czasie pandemii cholery i COVID-19 środkach medyczno-policyjnych. W XIX w., podobnie jak dziś, zamykano szkoły, teatry, ale otwarte pozostawały kościoły. Choć nabożeństwa się w nich nie odbywały (oprócz wyznaczonych przez biskupa mszy dedykowanych odwróceniu zarazy), drzwi do świątyń pozostawały otwarte przez całą dobę, dzięki czemu wiernym umożliwiano modlitwę bez konieczności przebywania w tłumie ${ }^{29}$. Najdotkliwiej odczuwano zakaz odbywania się targów i jarmarków. Skutkowało to brakiem żywności oraz wzrostem cen. Szczególnie problem ten dotyczył miast, których ludność musiała sprowadzać prowiant $\mathrm{z}$ wiosek, nierzadko przy pomocy wojska i różnych faktorów (handlarzy), z którymi zawierano umowy. Na kordonach oraz granicach miast organizowano specjalne miejsca, gdzie dokonywano wymiany handlowej (tzw. tamownie) ${ }^{30}$. Aby zapobiec nadużyciom ze strony dostawców, ówczesne instrukcje kładły nacisk na kontrolę jakości sprzedawanej żywności, pilnując, by nie

\footnotetext{
28 Janicka, Sina śmierć z Azji, 386-387.

29 Rościsław Stasch, „Epidemja cholery azjatyckiej w Poznaniu w 1831 r.”, Archiwum Historii i Filozofii Medycyny oraz Historii Nauk Przyrodniczych, 13, z. 1-2 (1933): 106.

30 Zbigniew Olkowski, „Epidemia cholery azjatyckiej w Prusach Wschodnich w latach 1831-1832, Komunikaty Mazursko-Warmińskie 4 (1968): 541; Stasch, Epidemja cholery azjatyckiej w Poznaniu, 12-13.
} 
handlowano zepsutymi warzywami, mięsem lub artykułami fałszowanymi. Kontrolą taką objęte zostały także zajazdy, karczmy i restauracje.

Podobne obostrzenia w Polsce wprowadza się obecnie. W ramach tzw. lockdownu zamyka się placówki szkolne, kultury, zakłady usługowe i miejsca rozrywki. Ze względu na specyficzną drogę, którą dochodzi do zarażenia wirusem, zakazem prowadzenia działalności obejmuje się również miejsca oferujące usługi gastronomiczne lub hotelarskie. W czasie spadku liczby zachorowań przepisy liberalizuje się, co nie zmienia faktu, że normalne codzienne funkcjonowanie, praca czy wypoczynek są i tak mocno utrudnione. Rozwiązania przyjmowane na świecie są jednak różne. Niektóre kraje rezygnują z tak poważnych obostrzeń na rzecz bardziej liberalnych przepisów, co skutkuje zazwyczaj wzrostem liczby zarażeń. Przykładem tych ostatnich może być Szwecja, gdzie podczas pierwszej fali choroby (marzec 2020 r.) nie wprowadzono żadnych znaczących restrykcji. Pozostawiono otwarte granice, nie zamknięto szkół, zakładów pracy, kin czy restauracji. Rząd, podejmując taką decyzję, uzasadnił ją koncepcją „stadnej odporności” ${ }^{31}$. Podobnie początkowo na zarazę zareagowały Holandia i Wielka Brytania. Rzeczywistość, tj. szybko rosnąca liczba osób chorych oraz zmarłych, zweryfikowała jednak podejście tych krajów do wspomnianej koncepcji i ostatecznie wróciły one na tor obostrzeń. Podobne sytuacje miały miejsce również w czasie drugiej i trzeciej fali choroby.

Powszechność zachorowań wymusza tworzenie tymczasowych szpitali zakaźnych lub przekształcania oddziałów na zakaźne w szpitalach stacjonarnych. Jest to kolejny wspólny mianownik wszystkich pandemii. Działanie to nie jest dziś wcale łatwiejsze niż dawniej, zawsze bowiem wymaga dużych środków finansowych oraz zapewnienia personelu medycznego. $Z$ problemem niedostatecznej liczby lekarzy, zwłaszcza w sytuacjach kryzysowych, borykano się zawsze i właściwie w każdym kraju. Nie pomaga w jego rozwiązaniu podwyższenie stawek wynagrodzenia dla personelu medycznego oraz pomocniczego.

Pandemie cholery w XIX w. powtarzały się dość często. W opisywanym czasie było ich pięć (1817-1823, 1826-1837, 1841-1861, 1863-1875, 1881-1896). W samym Cesarstwie Rosyjskim cholera z przerwami pokazywała się przez ponad 20 lat. Doraźnie podejmowane środki nie zawsze szły w parze z reformami sanitarnymi, dlatego tym bardziej potrzebny był skuteczny środek profilaktyczny. W końcu, w latach osiemdziesiątych, arsenał broni przeciwko cholerze udało się powiększyć o szczepionkę. Prace nad nią, jak na ówczesne warunki i poziom rozwoju mikrobiologii, nie trwały jednak zbyt długo. Najpierw, w 1881 r., francuski prekursor mikrobiologii Louis Pasteur wyhodował kultury bakterii cholery,

${ }^{31}$ Koncepcja ta zakładała, że pandemię można zatrzymać w drodze nabywania przez ludność odporności, która w połączeniu ze szczepionką może przynieść pozytywne skutki, Magdalena Januszek, Bez restrykcji, bez problemu? Alternatywne podejście do problemu koronawirusa, https:// inzynieria.com/toptematcovid19/analizy_i_komentarze/58274,bez-restrykcji-bez-problemualternatywne-podejscie-do-koronawirusa, dostęp: 3 III $2021 \mathrm{r}$. 
które przetestował na drobiu, a następnie już trzy lata później, w 1884 r., hiszpański bakteriolog i lekarz Jaime Ferrán y Clúa trzykrotnie zaszczepił około 50 tys. mieszkańców hiszpańskiego miasteczka Tortosa. Szczepionka nie została jednak wcześniej dobrze przetestowana, wskutek czego znaczna liczba z nich zmarła ${ }^{32}$. Znacznie lepiej poszło kolejnemu bakteriologowi, Mordechajowi Wolffowi Haffkinowi. Z powodzeniem przeprowadził on test szczepienny na sobie, a następnie udał się do Indii, gdzie w latach 1893-1895 zaszczepił około 25 tys. ochotników, spośród których zdecydowana większość przeżyła ${ }^{33}$. Z roku na rok, zwłaszcza tam gdzie choroba występowała endemicznie, przybywało chętnych do podania kultur Vibrio cholerae. Dokonał się wówczas prawdziwy przełom, nie tylko w bakteriologii, ale i społeczny - powoli zaczął zmieniać się stosunek do szczepień. Ostatecznie, pomimo że choroba nadal występuje (także jako skutek katastrof naturalnych), udało się zmniejszyć liczbę chorujących na nią, a z Europy wyeliminować ją całkowicie ${ }^{34}$.

Również i obecnie wiele nadziei pokłada się w szczepieniach. Dzięki nowoczesnej technologii, wysokiemu poziomowi nauk medycznych, a także znacznej liczbie ośrodków naukowych biorących udział w opracowaniu szczepionki przeciwko COVID-19 - prace nad nią trwały niewiele ponad rok. W efekcie, w momencie powstawania niniejszego tekstu w Polsce dostępne są aż cztery jej warianty wyprodukowane przez różne firmy farmaceutyczne: Comirnaty (BioNTech/Pfizer), preparat koncernu Moderna, szczepionka AstraZeneca oraz Johnson\&Johnson ${ }^{35}$. Ich skład oraz zasady podawania (liczba szczepień i ilość przyjmowanego preparatu) są różne i na ostateczne wnioski odnoszące się do ich skuteczności jest jeszcze za wcześnie. W tej kwestii wypowiadać się jednak powinni lekarze.

Na koniec zamiast podsumowania - wniosek, zapewne ryzykowny, bo przeciwny temu, co dziś słyszymy lub czytamy w środkach masowego przekazu. Otóż zdaniem wielu osób obecna pandemia COVID-19 „zmieni wszystko” - gospodarkę,

32 Oprócz tego, że Clúa podał ją świnkom morskim, to test wykonał również na sobie i swoim współpracowniku. Jak się okazało, mieli oni szczęście i nie zachorowali, nie doszło również do żadnych powikłań, Lawrence K. Altman, Who goes first? The story of self-experimentation in Medicine (Berkeley-Los Angeles-London: University of California Press, 1998), 120-121; Stanisław Serkowski, Szczepienia przeciwcholeryczne i przeciwtyfusowe (Warszawa: Drukarnia Artystyczna Kazimierz Kopytkowski i S-ka, 1915), 15, 20.

33 Barbara J. Hawgood, „Waldemar Mordecai Haffkine, CIE (1860-1930): prophylactic vaccination against cholera and bubonic plague in British India”, Journal of Medical Biography, 15 (Feb. 2007): 11, http://www.jameslindlibrary.org/system/attachments/107/original/HaffkinePublished. pdf?1329306127, dostęp: 30 IV 2021 r.; Echenberg, Africa, 39-40.

34 W Europie przyczynił się do tego głównie wzrost świadomości społecznej w zakresie profilaktyki zdrowotnej, a także wiele reform sanitarnych (budowa wodociągów, kanalizacji, oczyszczalni wód itp.).

35 Porozmawiajmy o szczepionce, https://www.medonet.pl/porozmawiajmyoszczepionce/ szczepionka-na-COVID-19,COVID-19--szczepionki--kiedy-zaczynaja-dzialac--jak-sprawdzicodpornosc,artykul,23824574.html, dostęp: 30 IV 2021 r. 
politykę, zwłaszcza społeczną i prozdrowotną, a przede wszystkim ludzi i ich podejście do chorób zakaźnych. O ile jednak rzeczywiście pandemia odbiła się na gospodarce i wielu innych dziedzinach życia państwa (już tego doświadczamy), to można chyba wątpić, czy faktycznie wpłynie ona na ludzi.

Badając zachowania i reakcje społeczności zarówno na pandemie cholery w XIX w., jak i wcześniejsze, te średniowieczne i nowożytne, jak dżumy, ospy, dezynterii i wielu innych zaraźliwych chorób, a następnie porównując je z obecnymi, trudno zauważyć, by dokonała się jakaś specjalna zmiana w kwestii podejścia do nich. Wydaje się, że z wielowiekowej lekcji, którą dały nam różne pandemie, jako populacja nie wyciągnęliśmy żadnych wniosków na przyszłość. Nasze zachowania cechuje pewna powtarzalność - brak wiary w istnienie choroby, podważanie autorytetów medycznych, niechęć do stosowania się do środków bezpieczeństwa, świadome łamanie obostrzeń antyepidemicznych. Niekiedy nadal można zaobserwować opory przed zgłaszaniem się do szpitali na leczenie czy na kwarantannę, samodzielnie ryzykowanie różnych terapii, pokładanie wiary w moc pokątnych „uzdrowicieli” i ich specyfików czy w końcu - odmawianie szczepień. Nie posiedliśmy umiejętności (a może chęci) korzystania z doświadczenia. Pocieszający w tym kontekście jest tylko fakt, że postawy te nie mają już dziś tak masowego charakteru, jak w XIX w., i że współczesna medycyna szybciej i skuteczniej potrafi poradzić sobie z większością chorób.

\section{Iwona Janicka}

\section{Cholera and COVID-19. Different diseases, common prevention measures}

Cholera and COVID-10 are two different diseases that have spread across the globe from Asia. The former is caused by the bacteria Vibrio cholerae, while the second is caused by a virus belonging to the corona virus group. Despite the differences in their course and treatment, one can find similarities in epidemic prevention measures imposed in the $\mathrm{XIX}^{\text {th }}$ century and currently. Actions in this area can be divided into hygienic-sanitary measures including personal care, such as, personal hygiene, physical and psychological health, and medical-policing procedures to prevent the spread of the disease. These last measures include: quarantines, cordons sanitaires, limitations of various kinds on social, cultural, and economic life. The common denominator in the case of both diseases is their avoidance via vaccination. 